\title{
Penerapan Terapi Bercakap-cakap Pada Pasien Gangguan Persepsi Sensori: Halusinasi
}

\author{
Ulfah Alfaniyah ${ }^{1 *}$, Yuni Sandra Pratiwi ${ }^{2}$ \\ ${ }_{1,2}$ Program Studi Diploma Tiga Keperawatan, Universitas Muhammadiyah Pekajangan \\ Pekalongan, Indonesia \\ *email: faniyah01@gmail.com
}

\begin{abstract}
Hallucination is a condition where a person experiences an unreal situation. That condition comes from the subconscious mind. Conversation therapy can be given to patients with hallucinations because they can reduce, overcame or control hallucination by keeping themselves busy through conversation activities. The purpose of this case study is to describe the application of speech therapy in patients with sensory perception disorders hallucinations. The method used in this study was a case study. The subject of this study was two patients who have impaired sensory perception of halluscinations. They were give the application of conversational therapy for nine days. The results of the study showed that the patients experienced an incrase in the ability to control hallucinations marked by a decrease in signs and symptoms of haluucinations after being given conversational therapy. It can be concluded that the application of conversational therapy is effective in inceasing the patient ability to control and reducing signs and symptoms of hallucinations. This result can be used as consideration for nurse to provide motivation, attention and improve the applicaton of conversation therapy in patients with hallucinations.
\end{abstract}

Keywords: Hallucinations, Conversation therapy

\begin{abstract}
Abstrak
Halusinasi merupakan suatu keadaan dimana seseorang sakit mengalami keadaan seperti tidak nyata, namun keadaan tersebut berasal dari alam bawah sadar. Pemberian terapi bercakap-cakap dilakukan untuk pasien halusinasi karena dapat mengurangi, mengatasi atau mengontrol halusinasi yang muncul dengan menyibukkan diri melalui aktivitas bercakapcakap. Tujuan dilakukan studi kasus ini untuk menggambarkan penerapan terapi bercakapcakap pada pasien gangguan persepsi sensori: halusinasi. Metode yang digunakan dalam karya tulis ilmiah ini adalah studi kasus dengan subjek studi kasus dua pasien yang mengalami gangguan persepsi sensori halusinasi yang diberikan penerapan terapi bercakapcakap selama 9 hari. Hasil studi kasus pasien mengalami peningkatan kemampuan mengontrol halusinasi ditandai dengan penurunan tanda dan gejala halusinasi setelah diberikan terapi bercakap-cakap. Studi kasus ini menunjukan bahwa penerapan terapi bercakap-cakap efektif meningkatkan kemampuan pasien dalam mengontrol serta menurunkan tanda dan gejala halusinasi. Saran diharapkan perawat dapat memberikan motivasi, perhatian serta meningkatkan penerapan terapi bercakap-cakap pada pasien halusinasi.
\end{abstract}

Kata kunci: Halusinasi; tarapi bercakap-cakap

\section{Pendahuluan}

Halusinasi merupakan suatu keadaan dimana seseorang sakit mengalami keadaan seperti tidak nyata, namun keadaan tersebut berasal dari alam bawah sadar. Orang sakit yang mengalami halusinasi biasanya menganggap bahwa apa yang dialaminya nyata, bahkan dengan keadaan tersebut ada beberapa orang sakit menganggap bahwa 


\section{Prosiding Seminar Nasional Kesehatan LembagaPenelitian dan Pengabdian Masyarakat Universitas Muhammadiyah Pekajangan Pekalongan}

2021

halusinasi yang dialaminya merupakan suatu masalah yang mengganggu, namun ada yang menganggapnya kesenangan dalam alam bawah sadarnya. Jumlah kasus halusinasi orang sakit yang mengalami halusinasi penglihatan ada 20\%, 70\% mengalami halusinasi pendengaran, $10 \%$ mengalami halusinasi lainnya. Selain kasus orang sakit yang mengalami halusinasi di Indonesia [1], salah satunya kasus halusinasi di Rumah Perlindungan Sosial Berbasis Masyarakat (RPSBM) kota Pekalongan yang juga menjadi perhatian. Ada 15 orang sakit yang mengalami halusinasi dari 26 orang sakit dengan gangguan jiwa di RPSBM Kota Pekalongan. Orang sakit yang mengalami halusinasi di tempat tersebut sering mengalami kekambuhan, kekambuhan yang sering terjadi yaitu tingkat emosi yang tidak stabil bahkan sampai membahayakan penghuni lain di tempat tersebut.

Hasil pengkajian menunjukkan bahwa pasien di RPSBM mengalami kekambuhan atau muncul halusinasi terus menurus dan memperburuk psikologis klien. Klien yang mengalami halusinasi juga berada pada tahap kesenangan yaitu menikmati halusinasinya atau berada dalam kendali halusinasi sehingga dapat menimbulkan masalah. Berbagai masalah lainnya akan timbul jika tidak ada upaya dalam menangani masalah halusinasi sehingga perlu dilakukan upaya komprehensif dimulai dari pencegahan berbagai faktor presipitasi hingga meminimalisir kekambuhan.Dampak dari berbagai masalah perilaku yang timbul dari orang sakit yang mengalami halusinasi mengakibatkan orang tersebut mengalami ketakutan yang berlebihan dalam menjalani aktivitas sehari-hari, serta kurang fokus dalam melakukan sesuatu [2]. Perilaku maladaptif yang dapat ditimbulkan dari halusinasi yang dialami orang tersebut adalah perilaku yang agresif yang dapat menyerang ketika dirinya merasa terganggu, ketakutakan atau panik yang berlebihan akibat dari halusinasi yang muncul. Berbagai masalah yang timbul akibat dari halusinasi memerlukan perhatian khusus dengan adanya penanganan untuk mengontrol halusinasi lebih lanjut dengan pemberian intervensi keperawatan pada pasien halusinasi.

Tindakan yang dilakukan pada pasien halusinasi, ada 4 tindakan keperawatan atau pemberian intervensi diantaranya mengontrol halusinasi dengan mengahardik halusinasi, mengontrol halusinasi dengan bercakap-cakap, mengontrol halusinasi dengan melakukan aspek positif, serta mengontrol halusinasi dengan minum obat secara teratur. Pemberian yang efektif dari 4 tindakan tersebut bagi penderita halusinasi adalah dengan terapi bercakap-cakap.

Pemberian terapi bercakap-cakap ini dilakukan dengan tujuan untuk mengurangi, mengatasi atau mengontrol halusinasi yang muncul lagi yaitu dengan menyibukkan diri melakukan aktivitas bercakap-cakap. Terapi bercakap-cakap merupakan opsi yang sesuai untuk diberikan kepada pasien halusinasi dibandingkan dengan cara menghardik, karena menunjukan hasil evaluasi yang lebih signifikan. Dibuktikan oleh peneliti sebelumnya, dengan data subjektif yang muncul pasien mengatakan cara mengontrol halusinasi dengan bercakap-cakap merupakan cara yang paling efektif untuk dirinya mengontrol halusinasinya [5]. Fenomena gangguan jiwa yang dialami oleh orang sakit yang mengalami halusinasi membuat penulis ingin menerapkan terapi bercakap-cakap sebagai upaya untuk mengatasi masalah tersebut, sehingga 


\section{Prosiding Seminar Nasional Kesehatan LembagaPenelitian dan Pengabdian Masyarakat Universitas Muhammadiyah Pekajangan Pekalongan}

diharapkan orang sakit yang mengalami halusinasi mampu mengontrol halusinasi, dan dapat berinteraksi dengan lingkungannya.

Permasalahan diatas membuat penulis mengangkat topik "Penerapan Terapi Bercakap-cakap Pada Pasien Gangguan Persepsi Sensori: Halusinasi" sebagai topik dalam karya tulis ilmiah ini. Penulis berharap agar pembaca mengetahui bagaimana asuhan keperawatan untuk menurunkan tanda dan gejala pada pasien halusinasi menggunakan metode terapi bercakap-cakap.

\section{Metode}

Penelitian ini menggunakan desain studi kasus. Studi kasus ini dilakukan di RPSBM Kota Pekalongan selama 9 hari. Subjek studi kasus ini adalah 2 pasien di RPSBM yang memenuhi kriteria inklusi yaitu, mengalami halusinasi pendengaran dan penglihatan, pasien halusinasi yang sudah melewati SP 1, pasien halusinasi yang mampu berkomunikasi dengan baik serta tidak mengalami gangguan komunikasi. Instrumen studi kasus dalam penelitian ilmiah ini adalah lembar asuhan keperawatan, SOP terapi bercakap-cakap, lembar pelaksanaan, lembar kriteria evaluasi tanda dan gejala halusinasi, dan lembar observasi terhadap kemampuan mengontrol halusinasi. Pengumpulan data pada penelitian ini menggunakan lembar observasi tanda dan gejala serta kemampuan pasien dalam mengontrol halusinasi. Data yang telah dikumpulkan diolah dengan cara melihat nilai pre dan post setelah diberikan terapi bercakap-cakap.

\section{Hasil dan Pembahasan Hasil}

Karakteristik responden disajikan dalam tabel sebagai berikut.

Tabel 3.1 Distribusi Fekuensi Responden Berdasarkan Demografi $(n=2)$

\begin{tabular}{lllll}
\hline & Usia & Jenis Kelamin & Pendidikan & Pekerjaan \\
\hline Responden 1 & 39 & Laki-laki & SD & Tidak bekerja \\
Responden 2 & 32 & Laki-laki & SMA & Tidak bekerja \\
\hline
\end{tabular}

Analisa data berdasarkan tabel 3.1 memperlihatkan bahwa responden 1 dan 2 memiliki persamaan jenis kelamin dan tidak bekerja, tetapi terdapat perbedaan usia pada responden 1 yang berusia 39 tahun dengan responden 2 yang berusia 32 tahun. Perbedaan lainnya ditemukan pada jenjang pendidikan responden 1 yang menempuh pendidikan samapi SD dan responden 2 yang sudah menempuh pendidikan sampai SMA.

Tabel 3.2 Distribusi Frekuensi Responden Berdasarkan Jenis Halusinasi ( $n=2)$

\begin{tabular}{lll}
\hline & $\begin{array}{l}\text { Halusinasi } \\
\text { Penglihatan }\end{array}$ & $\begin{array}{l}\text { Halusinasi } \\
\text { Pendengaran }\end{array}$ \\
\hline Responden 1 & Mengalami & Mengalami \\
Responden 2 & Mengalami & Mengalami \\
\hline
\end{tabular}




\section{Prosiding Seminar Nasional Kesehatan \\ LembagaPenelitian dan Pengabdian Masyarakat Universitas Muhammadiyah Pekajangan Pekalongan}

Hasil analisa berdasarkan tabel 3.2 data jenis halusinasi memperlihatkan bahwa terdapat persamaan jenis halusinasi yang dialami oleh responden 1 dan 2 yaitu megalami halusinasi penglihatan dan pendengaran.

Tabel 3.2 Distribusi Frekuensi Responden Berdasarkan Evaluasi Tanda dan Gejala halusinasi $(n=2)$

\begin{tabular}{lll}
\hline & pre & Post \\
\hline Responden 1 & 22 & 6 \\
Responden 2 & 20 & 4 \\
\hline
\end{tabular}

Hasil analisa berdasarkan tabel 3 data tanda dan gejala resiko halusinasi menunjukan bahwa sebelum dilakukan tindakan terapi bercakap-cakap tanda dan gejala yang dialami responden 1 sebanyak 22 dan responden 2 sebanyak 20 . Tanda dan gejala kedua responden setelah dilakukan terapi mengalami penurunan dimana responden 1 menjadi 6 dan responden 2 menjadi 4 tanda gejala.

\begin{tabular}{|c|c|c|c|c|}
\hline \multirow{3}{*}{$\begin{array}{c}\text { Tabel } 4 \\
\text { Distribusi } \\
\text { Responden } \\
\text { Kemampuan }\end{array}$} & & pre & Post & \multirow{3}{*}{$\begin{array}{c}\text { Frekuensi } \\
\text { Berdasarkan } \\
\text { Mengontrol }\end{array}$} \\
\hline & Responden 1 & 7 & 8 & \\
\hline & Responden 2 & 7 & 8 & \\
\hline
\end{tabular}

Hasil analisa berdasarkan tabel 3.4 data kemampuan mengontrol halusinasi memperlihatkan bahwa sebelum dilakukan terapi bercakap-cakap responden 1 dan 2 belum mampu mengontrol halusinasi yang dialaminya serta belum mampu mengenali halusinasinya.

\section{PEMBAHASAN Karakteristik Demografi}

Analisa karakterisitk demografi responden ditinjau berdasarkan karakteristik demografi memperlihatkan bahwa responden 1 dan 2 memiliki persamaan jenis kelamin dan jenis halusinasi, namun ditemukan perbedaan usia pada responden 1 berusia 39 tahun dan responden 2 berusia 32 tahun. Perbedaan lain ditemukan pada pendidikan, responden 1 memiliki riwayat pendikakan SD dan responden 2 memiliki riwayat pendidikan SMA. Pendidikan kedua responden memberikan pengaruh terhadap penurunan tanda dan gejala halusinasi yang dialami. Pendidikan akan berpengaruh pada segala aspek 


\section{Prosiding Seminar Nasional Kesehatan LembagaPenelitian dan Pengabdian Masyarakat Universitas Muhammadiyah Pekajangan Pekalongan}

2021

kehidupan manusia baik dari perasaan, pikiran maupun sikapnya. Semakin tinggi pendidikan maka semakin tinggi pula kemampuan dasar seseorang sakit dalam manajemen stress.

\section{Analisa Perbedaan Penurunan Hasil Evaluasi Tanda dan Gejala Sebelum Dan Sesudah Pemberian Terapi Bercakap-Cakap}

Hasil evaluasi tanda dan gejala halusinasi yang dialami responden 1 sebelum pemberian terapi bercakap-cakap ditemukan sebanyak 22 tanda dan gejala halusinasi, kemudian tanda dan gejala halusinasi turun menjadi 6 sesudah diberikan terapi bercakap-cakap. Sementara pada responden 2 sebelum pemberian terapi bercakapcakap ditemukan sebanyak 20 tanda dan gejala halusinasi kemudian setelah diberikan terapi bercakap-cakap, hasilnya juga menurun menjadi 4 tanda dan gejala halusinasi. Hasil penerapan terapi bercakap-cakap pada pasien gangguan persepsi sensori halusinasi sesuai dengan hasil penelitian yang dijadikan rujukan dalam penulisan karya tulis ilmiah ini [5].

Tanda dan gejala dinilai dari hasil observasi terhadap pasien serta ungkapan pasien, seperti pasien mengatakan mendengar suara-suara (suara yang mengajak berbicara, suara yang menyuruhnya melakukan sesuatu yang berbahaya), melihat sesuatu yang menakutkan, merasa takut atau senang dengan halusinasinya. Berdasarkan data objektif, pasien tampak bicara atau tertawa sendiri, mengarahkan telinga ke arah tertentu, ketakutan pada sesuatu yang tidak jelas [4]. Hasil pengkajian dari kedua responden ditemukan tanda dan gejala sesuai dengan kondisi tersebut.

Faktor presipitasi penyebab halusinasi yang dialami oleh kedua responden salah satunya faktor perkembangan responden, responden 1 kurang kehangatan adanya kehadiran keluarga yang mendukung atau memotivasi responden, sedangakan responden 2 memiliki kehangatan keluarga yang selalu mendukung dan memotivasi klien dalam perawatannya. Faktor tersebut juga mempengaruhi hasil evaluasi tanda dan gejala pada responden, karena responden 1 kehilangan kepercayaan diri dan belum mampu mengatasi stres [6].

Perbedaan ditemukan dari terapi bercakap-cakap terhadap penurunan tanda dan gejala halusinasi yang dialami responden. Perbedaan penurunan tanda dan gejala halusinasi setelah diberikan intervensi terapi bercakap-cakap dengan dosis dan tindakan yang sama dipengaruhi oleh karakteristik demografi pada kedua responden.

Hasil akhir evaluasi tanda dan gejala mengalami penurunan dari responden 1 dan 2 mengalami penurunan tanda dan gejala. Berbagai faktor yang mempengaruhi penurunan tanda dan gejala diatas. Namun, dari tanda dan gejala yang muncul ada beberapa gejala yang masih muncul yaitu responden 1 dan 2 masih mendengar suarasuara, namun responden sudah mampu mengatasi suaraa-suara tersebut [3].

\section{Analisa Efektivitas Penerapan Terapi Bercakap-cakap}

Halusinasi merupakan keadaan dimana sesorang sakit mengalami persepsi yang tidak nyata. Cara mengontrol halusinasi dengan bercakap-cakap merupakan cara paling efektif dalam mengontrol halusinasi. Penerapan terapi bercakap-cakap ini 


\section{Prosiding Seminar Nasional Kesehatan LembagaPenelitian dan Pengabdian Masyarakat Universitas Muhammadiyah Pekajangan Pekalongan}

2021

bertujuan agara responden merasa senang dalam bersosialisasi dengan lingkungannya [3]. Setelah diberikan terapi bercakap-cakap responden mengalami penurunan tanda dan gejala subjektif, responden mengatakan jarang mendengar suara-suara, responden jarang melihat bayangan, responden mulai dapat memfokuskan pikirannya, responden mampu mengingat informasi yang yang telah disampaikan. Hal ini juga dibuktikan dari adanya penurunan jumlah tanda dan gejala objektif yang dialami kedua responden setelah diberikan terapi bercakap-cakap yaitu, responden sudah tidaktertawa dan berbicara sendiri, responden sudah tidak komat-kamit, responden mampu bersosialisasi dengan lingkungan dan aktif dalam kegiatan ruangan. Hal tersebut terjadi karena terapi bercakap-cakap merupakan media untuk berkomunikasi atau berinteraksi dengan orang sakit lain dalam mengungkapkan pikiran yang sebelumnya tidak mampu diungkapkan. Aktivitas bercakap-cakap dilakukan dengan tujuan untuk mengurangi terjadinya halusinasi muncul kembali.

\section{Kesimpulan}

Hasil penetian terapi bercakap-cakap karakteristik demografi klien berusia produktik sebanyak $100 \%$, laki-laki sebanyak $100 \%$, berpendidikan SD sebanyak $50 \%$, berpendidikan SMA $50 \%$, tidak bekerja sebanyak $100 \%$. Studi kasus ini menunjukan bahwa penerapan terapi bercakap-cakap efektif menurunkan tanda dan gejala halusinasi pada pasien halusinasi sebelum diberikan terapi bercakap-cakap pada responden 1 tanda gejala yang ditunjukkan sejumlah 22 tanda gejala dan responden tanda gejala yang ditunjukkan sejumlah 20 tanda gejala. Sesudah diberikan terapi bercakap-cakap pada responden 1 dan 2 tanda gejala yang ditunjukkan sejumlah 6 dan 4 tanda gejala.Studi kasus ini menunjukan bahwa penerapan terapi bercakapcakap efektif meningkatkan kemampuan pasien dalam mengontrol. Pasien dapat mengikuti terapi bercakap-cakap sebagai terapi untuk mengontrol halusinasi.

\section{Referensi}

[1] Dinas Kesehatan Provinsi Jawa Tengah. (2016). Profil Kesehatan Provinsi Jawa Tengah Tahun 2016. Diambil dari www.dinkesjatengprov.go.id

[2] Hasriana, Nur Muhammad, dan Angraini Sri. 2013. Pengaruh Terapi Aktivitas Kelompok Sosialisasi Pada Klien Isolasi Sosial Menarik iri Di Rumah Sakit Khusus Daerah Provinsi Sulawesi Selatan. Diambil dari http://ejournal.stikesnh.ac.id

[3] Larasaty, L., \& Hargiana, G. (2019). Manfaat Bercakap-Cakap Dalam Peer Support Pada Pasien Dengan Gnagguan Sensori Persepsi: Halusinasi Pendengaran. Diambil

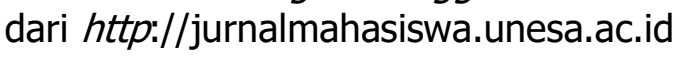

[4] Prabowo, E. (2014). Konsep dan Aplikasi Asuhan Keperawatan Jiwa. Yogyakarta : Nuha Medika.

[5] Wijayanti, L., Nufantri, Devi Chanitya, G.P. (2019). Penerapan Intervensi Menejemen Halusinasi Terhadap Tingkat Agitasi Pada Pasien Skizofrenia. Diambil dari https://media.neliti.com

[6] Yosep, H.I., \& Sutini, T. (2016). Buku Ajar Keperawatan Jiwa. Bandung: Refika Aditama 